\title{
Letting Smartphones at Class Times: Does It Matter in Learning Process?
}

\author{
Saban Kara ${ }^{1}$ \\ ${ }^{1}$ Department of Language, Faculty of Education, Tishk International University, Erbil, Iraq \\ Correspondence: Saban Kara, Tishk International University, Erbil, Iraq. \\ Email: saban.kara@ tiu.edu.iq
}

doi: 10.23918/ijsses.v7i1p78

\begin{abstract}
This research aimed to investigate the relation of learners' addiction to smartphones and its effect on their academic success. The researcher dealt with two language learning groups of Foundation Course students (The students whose English is in the elementary level and study at the departments on a condition to be successful in English subject at the end of the academic year) who lagged behind others academically during the academic year and failed at the end of the first year of their study at Preparatory School (of a prominent university located in Erbil, Iraq). Therefore, they had to attend summer school which requires retaking a 6-week summer course in a total of $\mathbf{1 2 0}$ hours. The researcher himself gave the writing course to the two defined groups. Observing the formative and summative test results in the total achievement grade table, the researcher concluded that the idea of letting smartphones to use can pave way for fruitful results in learners' comfort zone was a wrong perception. Without any hesitation, it hampered students' language learning pace and there was a causal relationship between learners' smartphone addiction at the lesson with their unsatisfactory total results.
\end{abstract}

Keywords: Academic Success, General English, Language Learning, Smartphone Addiction, Activities

\section{Introduction}

Despite remarkable improvements and innovations for humankind in search of illuminating the shades of the life, and adding more flavour to our lives, there are still some individuals who lack basic communication skills to convey messages and carry out their responsibilities in the age of social media. In the past, students' mind was not as full of time-consuming things like spending their valuable time in front of computer, a television and chat platforms as today (Yildiz, 2015a) and unfortunately, those lives are only busy with their self-images with no tentative plans. In the realistic world, the major problem that university students have is to define their future career. Educators have a paramount responsibility to develop learners' character via aim-based education (Tosun \& Yildiz, 2015). Learners derive much pleasure as they spend a large amount of time in their web-based lives. Their only concern was to perform their duties at school considering attendance and dive into virtual world where they can kill hours tirelessly without thinking about other requirements of courses like assignments, projects, research etc. Also, they have a greater responsibility not to feel satisfied with the given information. They must refresh their minds by novel ideas thanks to books, movies, articles, magazines etc. The underlying reason to witness such problems more and more is that the education system in the world is getting addicted to mobile phones and this web-based life in an increasing rate each passing day and it has been capturing more attention from different circles of the society as the days go by. In educators or learners' life, mobile phones are inevitable apparatus to use for leisure time activities, business, school which goes beyond their actual 
usage, school. Mobile phones are not just cell phones anymore when they are taken advantage of in many ways like shopping, writing articles, booking, navigation, acquiring different life-saving skills. Especially at hard times, people take advantage of them for video chatting, conference calls, picking up the necessary information, connecting people, educating students, etc. These features turn them into a miraculous remedy for troublesome situations.

Cell phones have an indispensable place in human connection thanks to their unique and unimaginable advantages compared to previous centuries. The cell phone is an incredible invention that has altered our lives forever. However, it is not uncommon to come across with the individuals who are unfilled with knowledge, lack of wisdom, etiquette and they can block all the channels to communicate because of their addiction to mobile. They should not be blamed for their actions which are not conform to established rules in society because the reality is, there is no real and ideal training to change this vicious cycle in organizations and family atmosphere where they are expected to conform to rules to have peace of mind and the notion of having strong communication skills is rather neglected in most cases. Whatever done to improve is ought to be utilized for mankind who needs satisfaction, solace, wellbeing, and ease. Commitment to this is highly important in terms of building a successful organizational system which will be more respectful and sustainable. Step by step instructions to conquer this issue are given with volunteers who are knowledgeable and committed their lives to instruction for the betterment of people`s lives and inter-personal relationships. Regardless of whether these volunteer mentors get into this addictive cycle, at that point, it should be admitted that the work will be so difficult, such a case that one kicks the bucket. We have been living in a high demanding era that life relates to life easy-make technology. It is invented to make our life comfortable, easy and timesaving. However, the new apps on the internet have been surrounding us cause less physical contact and prevented physical activities, reduced thinking, concentrating and memory skills, increased depressed, isolated and lazy (Issa \& Isaias, 2016), unhealthier, more introvert and unsociable generations by this web-based life. A huge number of individuals are there over the globe for various reasons. A major part of web-based life clients is comprised of adolescents where a large portion of them are understudies. Truth to be told, an ongoing overview of 3000 understudies from over the US demonstrates that $90 \%$ of undergrads utilize Facebook and $37 \%$ utilize Twitter (Questionnaire, 2011). There might be given several examples to this fact bringing details from Iraqi EFL learners: Spending 3 hours at least on social media, chatting or/ and messaging on the net for one hour are fact that the average time students spend in Iraq, like in many parts of the world. This evidence is based on a small survey conducted among 36 students. The young generation in Iraq, at the university level, is mostly dependent on social media especially to Facebook, Instagram, Snapchat, and so on. According to the educators of some foundation English classes at a private university (Foundation English course is for students whose English level is not sufficient to take core subjects in their departments and need extra English course prior to challenging departmental subjects) have noticed that students do not care about bringing books or notebooks to class although they are supposed to. It can be acceptable for a few days at the beginning of the year due to some problems related to availability of the books to be purchased, however, it cannot be justified in the following weeks if they don`t show up by their class materials to be equipped with learning. The class cannot be conducive to learning if the essential items are missing in class to follow the activities and participate when needed. While the instructors are trying to teach English in a committed and devoted way, giving tasks to engage learners to reach an objective by means of using 
the target language (Yildiz, 2020a), what they face on the desks are students' mobiles and their car keys which cause distraction for the students and demotivation for the instructors. Celik and Yildiz (2019) state that learning the cultural meaning and feelings of the target language can draw a learner's sympathy towards the target language as well as the student's learning motivation to the highest level. However, instructors lose their enthusiasm towards teaching when they face indifferent learners in large numbers. The new generation is uninterested in touchable books to read and go beyond their current levels which are prerequisites to stand on their professional careers in the future. Even though it is known that regular readers are academically successful comparing to non-book readers, learners in general do not care this reality (Yildiz, 2020b). These learner groups may be called 'generation Z'. This apathetic and uninterested generation puts the educators into worry since it is assumed that this generation will design the new world where it is expected to live fairly and peacefully by paying utmost attention to people`s basic rights. With this reality, putting the teaching into the centre as a profession, it can be said that committed teachers probably will be much more successful and can set up interaction among their students, organizations, professions, themselves and workgroup colleagues (Yildiz, 2017a). Besides, nowadays the world is desperate from coronavirus and due to this virus, like many countries, it is likely to have some implications of it in public and private sectors regarding to Kurdistan. Of course, a lot of people are hopeful about recovery of education soon, but from the educational point of view, not only teachers but also students have some concerns about this reality because no specific time is set when campus-based education commences precisely. To alleviate the adverse impacts of coronavirus pandemic, a growing number of public and private educational institutions have taken initiative for online classes globally and locally. Tishk International University was one of the pioneers of this process to offer world-class online education as early as possible with its dynamic academics located in Erbil and Slemani respectively. Even lecturers' and students' burnout actions (Shawkat, Celik, \& Budur, 2020) were noticed when they started online lessons on their mobile phones or computers because teaching online was not a simple task to be managed and kept under control easily. Students and educators must have a perfect internet connection to join online classes, computer literacy and most importantly eagerness to acquire knowledge in an increasing tone over the weeks.

\section{Theoretical Framework}

Letting students hold their smartphones to use in school education is certainly a hot topic. There is also a strong sense from classroom research that issues of distraction apply equally to laptops, iPads and other digital devices (Andersen, 2011). The new generation holds mobile phones daily to chat with their family and friends (Lenhart, 2010). Many comparable studies proved that learners who texted in their mobile phones during the lectures often gained unsatisfactory notes, less information, and did awful on tests about the material (Kuznekoff \& Titsworth, 2013). Relatively, although social media platforms seem to be beneficial in education, there has been an incredible worry among concerned people in training and guardians on the developing utilization of Facebook and its impact on teaching methods particularly among understudies at universities. Some educators see the future of learning as a personal matter (Kamenetz, 2019). Numerous academicians have a dread that time spent about disseminating the knowledge via web-based networking media is past the required time, this may prompt literary theft and protection issues and as a rule, contribute insignificantly to real understudy learning results. They regularly 
see utilizing web-based life as unnecessary or not favorable for better learning results (Moran et al., 2012). If a student is on social media, and not learning, not being inspired, not laughing, or not communicating, then the student is using it improperly. Today, students do not use their desktop computers, laptops or tablets as much as mobile phones to reach knowledge and broaden their horizon. Their world is the most sacred and secret in their mobile phones. Their priority is on mobile phones though personal computers offer much more to sharpen their computer literacy skills for their future professional career.

There are some of the quotes celebrities mentioned about social media and smartphones and their side effects (brainyquote.com, 2020). For instance, in the first quote, Daniel Goleman says that 'Smartphones and social media expand our universe. We can connect with others or collect information easier and faster than ever.' Mr. Daniel is right to some extent, yet the problem is how effectively we use them to take advantage of. On the other hand, Burnie Burns argues saying that 'I lived a significant portion of my life before the Internet and smart phones.' Moreover, John Rampton states how valuable is our time because 'We are surrounded by distractions. Whether they are emails, phone calls, text messages, social media notifications, or people entering and leaving your workspace, those distractions end up eating a good portion of your time.'

\section{Methodology}

\subsection{Materials and Procedures}

It was announced that thirty-six foundation course students had failed at the end of the academic year by the Prep School unit of the private university and those students were to take a summer course to pass the foundation English subject. Students were sat for the level test and sooner after the test they were asked to reply to general survey questions for the research. Immediately after that, students were distributed into two classes and the summer course commenced. The result of the research was partially stated in the abstract. Replies to the survey questions which are seen in the appendix part were accepted on the five choices Likert scale, and students expressed their opinion about using smartphones and social media. In this research, one of the classes as the experimental group of 19 students was not banned to use their smartphones while having a general English course and writing course throughout the weeks to sharpen their skills in English. On the other hand, the second class as the control group of 17 students was under strict pressure not to use their smart mobiles and was forced to turn off their phones in class no matter what the reason was to justify the usage of mobile phones. Students were examined by two pop quizzes and a final examination to measure their learning rate and determine successful and failed ones respectively. During the research, the control group and the experimental group students had weekly fourteen hours of general English course from a textbook and six hours of writing course from 'Reading and Writing Q-skills 1, written by Sarah Lynn, 2011'. Learners' language level was elementary and both groups had the same materials and smartboard techs in classes. The teacher that conducted the writing course for two classes was the researcher himself. Experimental group students were permitted to use their smartphones for educational purposes to provide them to feel the free atmosphere in class. However, the control group had to turn off their mobile phones during the class times despite its being quite annoying 
for the learners. During the weeks, students sat for two pop quizzes and one final examination. The grade average success tables were reasonably amazing and noteworthy to compare two groups.

\section{Findings and Discussion}

It has been studied that the worse about using mobiles in the classroom is that mobile device usage is distracting not only the user but the neighboring students. Many serious students thought that they would be able to keep their focus on the study in the classroom as using their smartphones actively (Glass \& Kang, 2019), but it appeared that keeping smartphones active harmed students' exam performance and final grades.

Despite the way that utilizing long-range social networking in the scholarly world has presented tremendous advantages, it isn't without a few cons and concerns. It is accounted for that the most influencing on in utilizing person to person communication from the scientific studies are the likelihood of investing a ton of energy in them and denying other critical viewpoints time they merit (Rowlands et al., 2011). In this context, we can advise that keeping mobiles off at the learning process at school is the key for learners who wish to succeed in their courses and finally, it is an inevitable fact that students are not able to get away from mobile phones. Hence, administrators must design guidelines for schools planning to adopt mobile phones in the curricula (Keengwe et al., 2014).

\subsection{Survey Statements to Analyze}

Table 1: Statements in the Likert Scale

\begin{tabular}{|l|c|c|c|c|c|}
\hline \multicolumn{1}{|c|}{ Survey Statements } & $\begin{array}{c}\text { Strongly } \\
\text { disagree }\end{array}$ & Disagree & Neutral & Agree & $\begin{array}{c}\text { Strongly } \\
\text { agree }\end{array}$ \\
\hline $\begin{array}{l}\text { 1-I use my smartphone for learning the } \\
\text { English language. }\end{array}$ & 3 & 12 & 20 & 1 & \\
\hline $\begin{array}{l}\text { 2-Students should bring their } \\
\text { smartphones for educational purposes to } \\
\text { class. }\end{array}$ & 5 & 8 & 10 & 7 & 6 \\
\hline $\begin{array}{l}\text { 3- I am addicted to using my } \\
\text { smartphones. }\end{array}$ & 7 & 1 & 28 & 2 & \\
\hline $\begin{array}{l}\text { 4- Using social media on my } \\
\text { smartphone prevents me from } \\
\text { concentrating on lessons. }\end{array}$ & 2 & 3 & 15 & 12 & 4 \\
\hline $\begin{array}{l}\text { 5- I am on social media for three hours } \\
\text { or more a day. }\end{array}$ & & & 2 & \\
\hline
\end{tabular}

In table 1, to analyze the first statement, it is seen that students generally do not use their smartphones for educational purposes, so it does not help much enough if the learners are not directed how to benefit from it. However, the second statement demonstrates that students cannot bear without their mobile phones 
because of their addiction. Although students' addiction to their mobiles is a fact, they do not accept themselves to be addicted, and do not agree with the idea that holding mobile phones or using social media distracts them from learning. The other reality is that they are all active users of social media and the average time they spent on social media is nearly three hours in both groups.

\subsubsection{Experimental Group Students' 6 Week Average}

The experimental group members were 19 in total and they were all at the elementary level. In order to pass the summer course, a student's total average of two quizzes and final exam must be 50 over 100 . Students were sat in class 111 randomly. They were warned to come to lessons $\% 90$ percent throughout the course, supposed to take 84 hours of general English from a textbook and 36 hours of intensive writing course. However comfortable the students were to use their mobile phones for educational reasons, their class average was 60 and 5 students of class 111 failed at the end of the summer course.

Table 2: Experimental Group Students' Summative Test Result after 6 Week

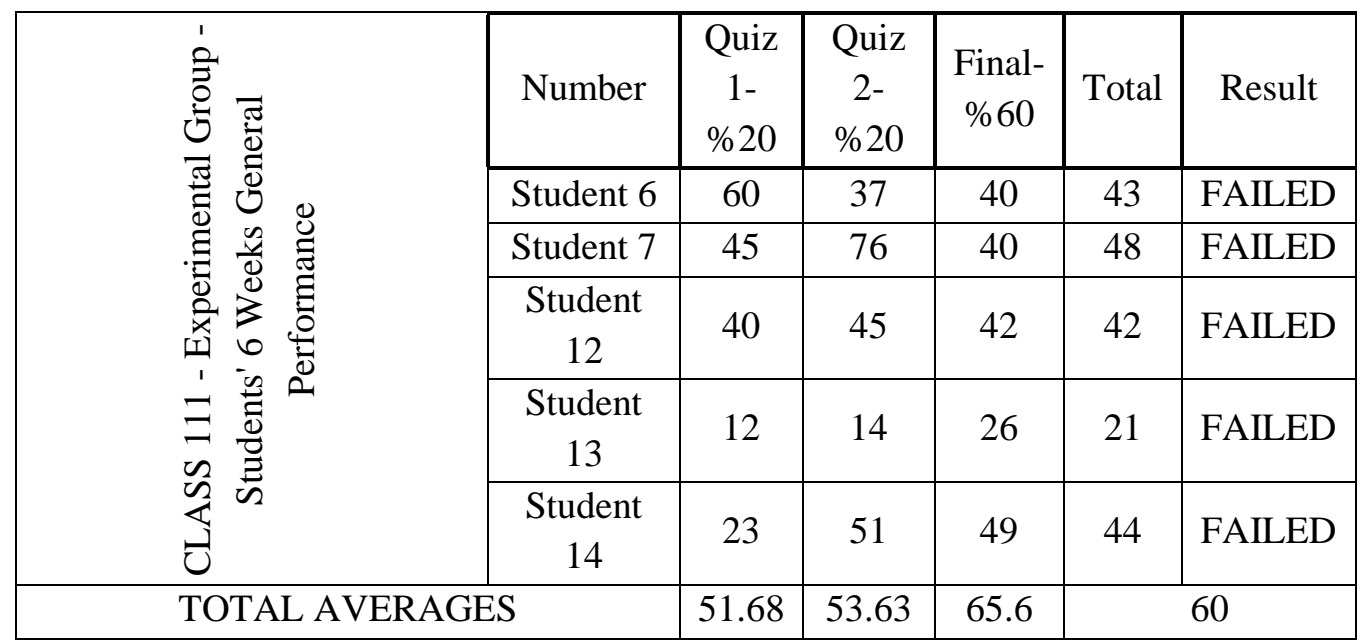

\subsubsection{Control Group Students' 6 Week Average}

The control group members were 17 in total and they were all at the elementary level. In order to pass the summer course, a student's total average of two quizzes and final exam must be 50 over 100. Students were sat in class 113 randomly. They were warned to come to lessons $\% 90$ percent throughout the course, supposed to take 84 hours of general English from a textbook and 36 hours of intensive writing course. However, they were restricted to use their mobile phones at all during the lesson and their class average turned to 67, and surprisingly only 2 students failed from class 113 at the end of the summer course. 
Table 3: Control Group Students' Summative Test Result after 6 Week

\begin{tabular}{|c|c|c|c|c|c|c|}
\hline \multirow{3}{*}{ 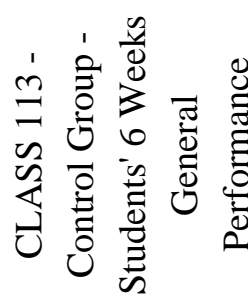 } & Number & $\begin{array}{c}\text { Quiz } \\
1- \\
\% 20\end{array}$ & $\begin{array}{c}\text { Quiz } \\
2- \\
\% 20\end{array}$ & $\begin{array}{l}\text { Final- } \\
\% 60\end{array}$ & Total & Result \\
\hline & Student 4 & 21 & 66 & 46 & 45 & FAILED \\
\hline & $\begin{array}{c}\text { Student } \\
14\end{array}$ & 23 & 42 & 60 & 49 & FAILED \\
\hline TOTAL AV & & 52.82 & 63.88 & 71.9 & & 67 \\
\hline
\end{tabular}

\subsubsection{Students' 6 Week Performance in Chart}

This chart demonstrates the negative effect of keeping mobile phones in lessons. The marked average between two classes is reasonably huge at the end of the six-weeks summer course.

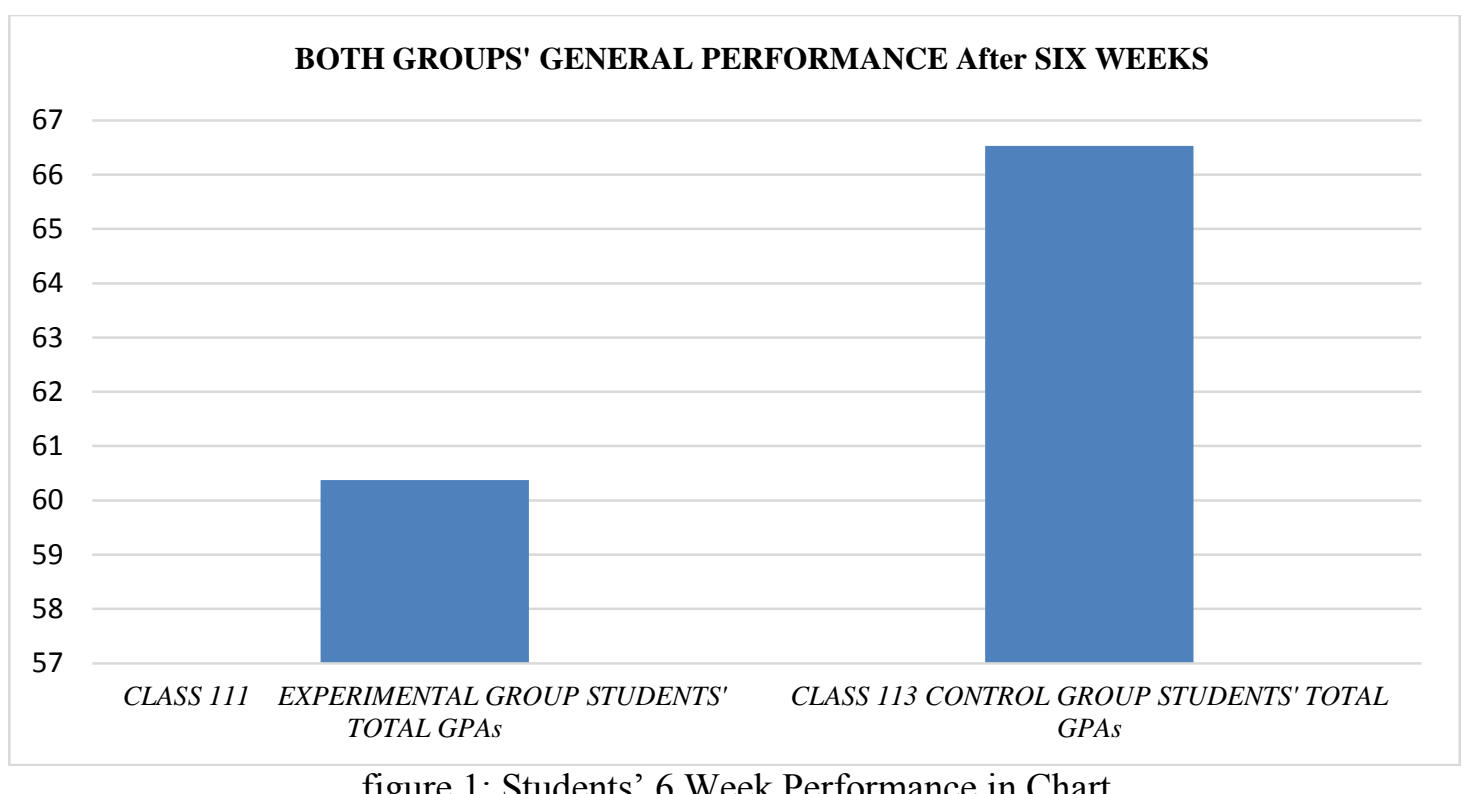

figure 1: Students' 6 Week Performance in Chart

\section{Conclusions}

In this era, no one directly claims that social media is wrong in a learner's life, yet it has myriad disadvantages comparing to its advantages. Although every invention is intended for the benefit of mankind, inventions that are unrestricted in use (televisions, computers, mobiles), or inventions that cannot be controlled on a personal basis (social media) continue to ring danger bells for humanity in the long run. There are many insightful and inspiring talks, blogs, conferences, and webinars about the use of technology, the use of social media, learning beyond walls to name a few. All platforms or devices are in the service of educators, learners, or hungry purposeful learners. Yet, there are a lot of difficulties to draw students' attention to the learning atmosphere while they are holding their mobiles which seem to be more appealing than lecturing in the classroom. Though they may have many destructive effects in classes, it 
takes time to realize that the disadvantages outweigh its advantages. Because of this reality, the researcher claims that keeping mobile phones on while studying a language in a class will cause the concentration away and distract the holder from following the lesson. Whatever the fact is, in a recent Pearson study says that a great number of Generation $\mathrm{Z}$ learners wish to learn from YouTube and videos pretty much more than printed books. However, today in some European countries, bringing a mobile phone to school has been banned. In CNN news, Smith (2018), reported that 'French children will have to leave their smartphones and smart devices at home or switched off when they are at school starting in September 2018.' Miley (2018) states that all internet-connected devices will have to be left at home or be turned off when on the school grounds according to a new ban in France. Although mobile phones are a part of our life and inevitable fact, it is recommended that students should turn off their mobiles while taking lessons in education buildings like in the example above. Yet it is the reality that smart mobile holders are addicted to using them and because of their distraction, learners cannot turn their head direct to whatever they are supposed to gain. Though the aim is to use the tech. for educational purposes, it is difficult to motivate students to use the devices on their learning benefits. In the end, some of the learners fail in concentration, become unsuccessful, and need to retake the course for the upcoming year.

\section{Suggestions}

There may be a lot of talks about smartphone and social media addiction as a type of internet addiction and/or a mental health problem. Users of social media might need professional therapies unless the usage of it limited. Educators formally teach learners the given curriculum and whatever they teach, the outcomes must be mentioned or handed in paper beforehand to learners clearly (Yildiz, 2017b). The learners must be clarified about not using smartphones in classes in any circumstances. They should be encouraged, motivated to understand the value of education, the necessity of learning a foreign language, coming to classes on time, studying regularly, and being serious. Besides, as being educators or the stakeholders, we cannot prevent students from bringing their mobile phones to educational institutions, but we may stop them using their devices during the course by special transmitting devices or setting up jammers, especially for crowded classes if they are permitted legally to be installed for the well-being of classes. As a result, these devices might prevent coming phone calls, and distracting noises or messages. Consequently, students will only be able to use their smartphones as a dictionary tool in language classes. To sum up, having the internet to use social media on mobiles can be important and convenient for educational purposes, but smartphones with social media apps affect a language learner's academic success adversely. To conclude, extracurricular activities are a useful theme in education that can create a positive atmosphere in students' life (Yildiz, 2015b) and for those, smartphones can be used as a supplementary tool to practice and to give additional tasks in students' usual online platforms such as WhatsApp, Viber, Twitter, Instagram, etc. (Yildiz, 2019).

\section{References}

Andersen, E. (2011). Cell Phones in School: Tools or Toys?(2009). Dostupný z WWW:< http://journalstar. com/lifestyles/article_b851282e-941c-11de-b6d1-001cc4c002e0. html.

Brainyquote.com, (2020). Retrieved from https://www.brainyquote.com/search_results?q=social+media 
Celik, B., \& Yıldız, Y. (2019). The role of foreign language culture on teaching the language and learner motivation. International Journal of Social Sciences \& Educational Studies, 5(4), 150.

Glass, A. L., \& Kang, M. (2019). Dividing attention in the classroom reduces exam performance. Educational Psychology. https://doi.org/10.1080/01443410.2018.1489046

Issa, T., \& Isaias, P. (2016). Internet factors influencing generations $\mathrm{Y}$ and $\mathrm{Z}$ in Australia and Portugal: A practical study. Information Processing and Management. https://doi.org/10.1016/j.ipm.2015.12.006

Kamenetz, A. (2019). The future of learning? Well, It's Personal. NPR News.

Keengwe, J., Schnellert, G., \& Jonas, D. (2014). Mobile phones in education: Challenges and opportunities for learning. Education and Information Technologies. https://doi.org/10.1007/s10639-012-9235-7

Kuznekoff, J. H., \& Titsworth, S. (2013). The Impact of Mobile Phone Usage on Student Learning. Communication Education. https://doi.org/10.1080/03634523.2013.767917

Lenhart, A. (2010). Cell phones and American adults: They make just as many calls, but text less often than teens. Pew Research Center.

Miley, J. (2018). France has banned students from using smartphones and tablets at school. Interesting Engineering.

Moran, M., Seaman, J., \& Tinti-Kane, H. (2012). Blogs, wikis, podcasts and Facebook: how today's higher education faculty use social media. Pearson.

Questionnaire, S. (2011). ECAR national study of undergraduate students and information technology , 2011. Technology.

Rowlands, I., Nicholas, D., Russell, B., Canty, N., \& Watkinson, A. (2011). Social media use in the research workflow. Learned Publishing. https://doi.org/10.1087/20110306

Shawkat Mohammed, S., Suleyman, C., \& Taylan, B. (2020). Burnout determinants and consequences among university lecturers. Revista Amazonia Investiga. https://doi.org/10.34069/ai/2020.27.03.2

Tosun, M., \& Yildiz, Y. (2015). The role of moral values and systematic informing in aim-based education. International Journal of Social Sciences \& Educational Studies, 2(2), 40-44.

Yildiz, Y. (2015a). Time spent in target language-oriented extracurricular activities and foreign language students' satisfaction. 5th International Research Conference on Education, Tbilisi, Georgia, 478-482.

Yildiz, Y. (2015b). Better education at Ishik University preparatory school with extracurricular activities. Advances in Language and Literary Studies, 6(4), 158-161.

Yildiz, Y. (2017a). Components of commitment to the teaching profession. International Journal of Social Sciences \& Educational Studies, 4(2). https://doi.org/10.23918/ijsses.v4i2sip115

Yildiz, Y. (2017b). Extracurricular Activities in the Steps of Aim-Based Education. International Journal of Social Sciences \& Educational Studies, 4(2). https://doi.org/10.23918/ijsses.v4i2sip129

Yildiz, Y. (2019). EFL learners' needs in preparatory schools and supplementary techniques to improve their language proficiency. International Journal of Academic Research in Business and Social Sciences, 9(1). https://doi.org/10.6007/ijarbss/v9-i1/5460

Yildiz, Y. (2020a). Task-Based language teaching: An approach in the spotlight to propel language learning forward. International Journal of Social Sciences \& Educational Studies. https:// doi: 10.23918/ijsses.v7i1p72

Yildiz, Y. (2020b). Reading habit and its role on students' academic success at language preparatory school: A Research on Tishk International University preparatory school students. Amazonia Investiga, 9(27), 189-194. 


\section{Appendix}

\section{Survey Questions}

Dear Student.

Using smartphones, electronic devices, and social media in learning and teaching a language is a new issue in education. We would like to find out some answers to the hypothesis which is: students' general performance grade average will result positively in case of allowing them to use mobile phones for educational purposes at lesson time. To get some feedback before the research, there are five statements below we would like you to circle or underline one of them based on your preference. You are not asked to write your name on the survey sheet; it is only for feedback. Your cooperation is valuable for collecting precise data and thank you for your participation in this study.

\section{Statements}

1. I use my smartphone for learning the English language.
a. Strongly disagree
b. Disagree
c. Neutral
d. Agree
e. Strongly agree

2. Students should bring their smartphones for educational purposes to class.
a. Strongly disagree
b. Disagree
c. Neutral
d. Agree e. Strongly agree

3. I am addicted to using my smartphone phone.
a. Strongly disagree
b. Disagree
c. Neutral
d. Agree
e. Strongly agree

4. Using social media on my smartphone prevents me from concentrating on lessons.
a. Strongly disagree
b. Disagree
c. Neutral
d. Agree
e. Strongly agree

5. I am on social media for three hours or more a day.
a. Strongly disagree
b. Disagree
c. Neutral
d. Agree
e. Strongly agree 